\title{
Nitrogen uptake rates in phytoplankton and ice algae in the Barents Sea
}

\author{
SVEIN KRISTIANSEN and TOVE FARBROT
}

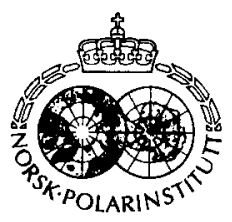

\begin{abstract}
Kristiansen, S. \& Farbrot, T. 1991: Nitrogen uptake rates in phytoplankton and ice algae in the Barents Sea. Pp. 187-192 in Sakshaug, E., Hopkins, C.C.E. \& Øritsland, N. A. (eds.): Proceedings of the Pro Mare Symposium on Polar Marine Ecology, Trondheim, 12-16 May 1990. Polar Research IO(I).

Uptake rates of $\mathrm{NH}_{4}^{+}, \mathrm{NO}_{3}^{-}$and dissolved organic nitrogen (urea) were measured in phytoplankton and in ice algae in the Barents Sea using a ${ }^{15} \mathrm{~N}$-technique. $\mathrm{NO}_{3}^{-}$was the most important nitrogen source for the ice algae (f-ratio $=0.92$ ). The in situ irradiances in the subsurface chlorophyll maximum and in the ice algal communities were low. The in situ $\mathrm{NO}_{3}^{-}$uptake rate in the ice algal communities was light-limited The in situ $\mathrm{NO}_{3}^{-}$and $\mathrm{NH}_{4}^{+}$uptake rates in the subsurface chlorophyll maximum were at times light-limited. It is hypothesised that $\mathrm{NH}_{+}^{+}$may accumulate in low light in the bottom of the euphotic zone and inhibit the in situ $\mathrm{NO}_{3}^{-}$uptake rate.
\end{abstract}

Suein Kristiansen and Tove Farbrot, Department of Biology, Marine Botany Section, University of Oslo, P.O. Box 1069, Blindern. N-0316 Oslo 3. Norway (revised February 1991).

\section{Introduction}

Nutrient concentrations in the Barents Sea vary considerably through the year. During winter nutrient concentrations are high due to vertical mixing of the water column. During spring and summer the water column becomes stratified, phytoplankton grows, and an oligotrophic surface layer develops south of the marginal ice zone. At the same time a pronounced subsurface chlorophyll maximum is formed at the nutricline (Kristiansen \& Lund 1989; Loeng 1989; Rey \& Loeng 1985). Several ice algal communities have been identified in the Barents Sea (Horner et al. 1988). The ice algal biomass, especially in the sub-ice assemblage, may be very high, and has been suggested to be an important part of the ecosystem in the Barents Sea (Syvertsen 1991 this volume). Irradiance is low in both the subsurface chlorophyll maximum (Rey \& Loeng 1985) and in the ice algal communities (E. E. Syvertsen pers. commun.), and algal cells in some of these communities have been shown to be shadeadapted (Sakshaug 1989). Kristiansen \& Lund (1989) found that $\mathrm{NH}_{4}^{+}$concentrations $>0.8 \mu \mathrm{mol}$ $\mathrm{I}^{-1}$ significantly reduced $\mathrm{NO}_{3}^{-}$uptake in the low light regime in the subsurface chlorophyll maximum. The uptake rates of $\mathrm{NH}_{4}^{+}, \mathrm{NO}_{3}^{-}$and urea in these low light and often nutrient-rich environments, the subsurface chlorophyll maximum, and the sea ice algal communities will be discussed.

\section{Materials and methods}

The samples from the subsurface chlorophyll maximum were collected during four cruises in the central parts of the Barents Sea in May-June and in August 1984 (Kristiansen \& Lund 1989), in July-August 1985, and in May-June 1987. The ice algae were sampled during four cruises into the ice by divers using gentle suction from a submersible pump (Lønne 1988) or by scraping algae off the ice (Fig. 1). It has been observed that the algal cells usually float directly beneath the ice, making quantitative sampling difficult.

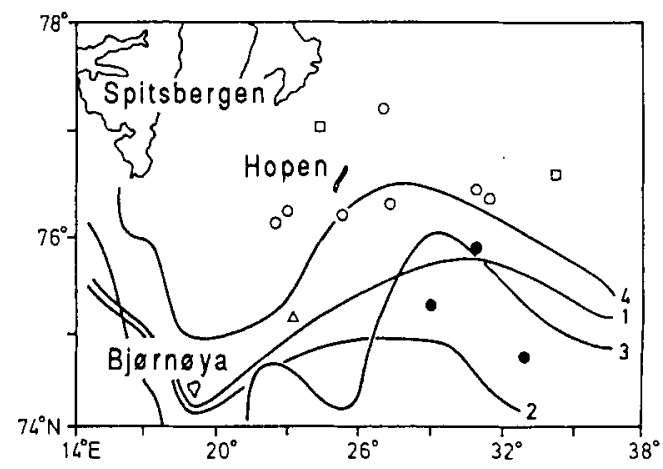

Fig. I. Stations in the Barents Sea where ice algal samples were collected. The curves represent the approximate southern limit of the sea ice during each of the four cruises. $1(\Delta), K / V$ NORDKAPP in February-March 1987: 2 (O), K/V SENJA and K/V ANDENES in April 1986; 3 (O). $\mathrm{K} / \mathrm{V}$ ANDENES in May-June 1988; 4 ( $\square)$, R/V LANCE in May-June 1986. 
The samples were diluted to contain less than $50-75 \mu \mathrm{g} \mathrm{Chl} 1^{-1}$ before incubation. The values presented here have been corrected for the dilution procedure. The nitrogen uptake rates were measured using the stable isotope ${ }^{15} \mathrm{~N}$. The methods used are given in Kristiansen \& Lund (1989). The uptake rates are calculated in situ absolute uptake rates in mol $\mathrm{l}^{-1} \mathrm{~h}^{-1}$ unless other-

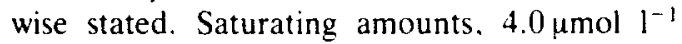
$\mathrm{NH}_{4}^{+}$or urea-N or $8.0 \mu \mathrm{mol} \mathrm{NO}{ }_{3}^{+}$. of the isotopes $\left(95-99\right.$ atom $\left.\%{ }^{15} \mathrm{~N}\right)$ were used in the experiments. The half-saturation coefficients used in the calculations of the in situ rates were $1.3 \mu \mathrm{mol}^{-1}$ for $\mathrm{NH}_{4}^{+}, 1.8 \mu \mathrm{mol} \mathrm{l}^{-1}$ for $\mathrm{NO}_{3}^{-}$and $0.2 \mu \mathrm{mol} 1^{-1}$ for urea- $\mathrm{N}$. These half-saturation coefficients are typical for $\mathrm{NO}_{3}^{-}$-rich Barents Sea water containing $>1 \mu \mathrm{moll}^{-1}$ (pers. observation): in $\mathrm{NO}_{3}^{-}$-poor Barents Sea Water $\left(<1 \mu \mathrm{mol}^{-1}\right)$, the half-saturation coefficients for the three nutrients were $0.1-0.2 \mu \mathrm{mol} l^{-1}$. The growth rate, $\mu$, in doubl. $h^{-1}$. was calculated as: $\mu=\rho *(\mathbf{P N} *$ $\ln 2)^{-1}$ where $\rho$ is summed in situ absolute uptake rate of $\mathrm{NO}_{3}^{-}+\mathrm{NH}_{4}^{+}$+ urea in $\mu \mathrm{moll}^{-1} \mathrm{~h}^{-1}$ and $\mathrm{PN}$ is particulate nitrogen in $\mu \mathrm{moll}^{-1}$. Scalar irradiance beneath the ice was measured using a $4-\pi$ collector (Biospherical Instruments inc.. model QSL-140), and the irradiance in the incubator was adjusted accordingly with stainless steel nets. At one station. in March 1987. quantitative ice algal samples were incubated in in situ incubation chambers. The chambers were acrylic cylinders closed in one end. $11 \mathrm{~cm}$ in diameter and $950 \mathrm{ml}$ capacity. Tightly fit acrylic lids were used to cap off the chambers after sampling. The isotope was added through a septum mounted in each lid. The chambers were filled. capped off. and isotopes were added. all under the ice. and the chambers were left to incubate under the ice.

\section{Results and discussion}

The $\mathrm{NO}_{3}^{-}$concentration was typically about $13 \mu \mathrm{moll}^{-1}$ in the whole water column during winter and below the pycnocline during summer (Table 1). In the oligotrophic surface layer the $\mathrm{NO}_{3}^{-}$concentration was usually not detectable. The concentrations of $\mathrm{NH}_{\downarrow}$ and urea were usually $<0.3 \mu \mathrm{mol} \mathrm{I}^{-1}$. At stations with a pronounced subsurface chlorophyll maximum, however, a subsurface $\mathrm{NH}_{+}^{+}$maximum was often found associated with the chlorophyll peak (Table 2).
During the productive season, high $\mathrm{NH}_{4}^{+}$concentrations were found also in the ice/water interface (Table 2). In winter the $\mathrm{NH}_{4}^{+}$concentration was $<0.1 \mu \mathrm{mol} \mathrm{1^{-1 }}$.

The sampled ice algal biomass was very high and variable (Table 3 ). though not unexpectedly considering the sampling methods used. The mean ratio between particulate carbon and nitrogen $(\mathrm{C}: \mathrm{N})$ in the ice algae and in the water column in the marginal ice zone (MIZ, as defined in Vincent 1988) were both close to 7 which is typical for multispecies communities of phytoplankton (Redfield et al. 1963). The mean ratio between chlorophyll $a$ and particulate organic $\mathrm{C}(\mathrm{Chl} / \mathrm{C})$ was 2.6 times and 13.8 times higher in the ice algal communities than in the water column in $\mathrm{MIZ}$ and in the oligotrophic surface layer south of MIZ respectively (Tables 3 and 6). This indicates that the ice algal communities were shadeadapted (Sakshaug 1989). The $\mathrm{C}$ and $\mathrm{N}$ values have not been corrected for non-phytoplankton carbon, and the $\mathrm{Chl} / \mathrm{C}$ ratios are minimum estimates. A mixture of one-year and multi-year ice was found at the two northernmost stations (Fig. 1). and one-year ice dominated at the other stations (pers. observations; Syvertsen 1986, 1987, 1988: Vinje 1987). The sub-ice assemblage was the dominating ice algal community both in oneyear and in multi-year ice. Dominating species were Nitzschia frigida and Thalassiosira spp. in one-year ice and Melosira arctica in multi-year ice (Syvertsen 1986, 1987, 1988; E. N. Hegseth pers. commun.).

The mean uptake rates in the ice algal communities and in the water column in MIZ are compared in Table 4 . The summed absolute uptake rate $\left(\mathrm{NH}_{4}^{+}+\mathrm{NO}_{3}^{-}+\right.$urea) in the ice algal communities was high and variable, mainly because the sampled biomass was variable. The

Table l. Typical concentrations of $\mathrm{NO}_{3}^{-}, \mathrm{NH}_{+}$, urea-N, and particulate organic nitrogen (PN) in $\mu \mathrm{mol} \mathrm{I}^{-}$in the Barents Sea during winter and during summer in the oligotrophic surface laver and in deep water.

\begin{tabular}{llll}
\hline & & \multicolumn{2}{c}{ Summer } \\
\cline { 3 - 3 } Nutrient & Winter & $\begin{array}{l}\text { Oligotrophic } \\
\text { surface layer }\end{array}$ & $\begin{array}{l}\text { Decp } \\
\text { water }\end{array}$ \\
\hline $\mathrm{NO}$ & 13 & 0 & 13 \\
$\mathrm{NH}$ & $<0.1$ & $<0.3$ & $<0.1$ \\
Lica-N & $<0.1$ & $<0.2$ & $<0.1$ \\
$\mathrm{PX}$ & $<0.5$ & $1.6-1.8$ & $<0.5$ \\
\hline
\end{tabular}


Table 2. Concentrations of $\mathrm{NH}_{4}^{+}$in the subsurface chlorophyll maximum, in the oligotrophic surface layer, in the ice/seawater interface and in the water column $0.3 \mathrm{~m}$ under the ice during the productive season.

\begin{tabular}{lllr}
\hline Sample & $\begin{array}{l}\text { Range } \\
\left(\mu \mathrm{mol}^{-1}\right)\end{array}$ & $\begin{array}{l}\text { Means } \pm \mathrm{SE} \\
\left(\mu \mathrm{mol}^{-1}\right)\end{array}$ & $\mathrm{n}$ \\
\hline Subsurface chloroph. max. & $0.11-2.28$ & $0.67 \pm 0.08$ & 40 \\
Oligotrophic surface layer & $0.09-0.39$ & $0.25 \pm 0.02$ & 23 \\
Ice/seawater interface & $0.40-2.51$ & $1.17 \pm 0.42$ & 5 \\
0.3 m under the ice & $0.05-0.58$ & $0.33 \pm 0.11$ & 5 \\
\hline
\end{tabular}

Table 3. Concentrations of chlorophyll $a\left(\mu \mathrm{g}^{-1}\right)$ and of particulate organic nitrogen (PN in $\left.\left.\mu m o l\right)^{-1}\right)$, atomic ratio between particulate organic carbon and nitrogen $(\mathrm{C} / \mathrm{N})$ and ratio between chlorophyll $a$ and particulate organic carbon $(\mathrm{Chl} / \mathrm{C}$ in $\mathrm{g} / \mathrm{g})$ in the ice algal samples and in the water column in the marginal ice zone. Mean \pm standard error and number of samples ( $\mathrm{n}$ ) are given.

\begin{tabular}{llllll}
\hline Sample & Chl & PN & C/N & \multicolumn{1}{c}{$\begin{array}{l}\text { Chl/C } \\
(\times 1000)\end{array}$} & n \\
\hline Ice algac & $1260 \pm 558$ & $227 \pm 65$ & $8.6 \pm 0.5$ & $41.4 \pm 5.2$ & $418(9)$ \\
hWatcr col. & $2.0 \pm 0.6$ & $1.11 \pm 0.17$ & $10.0 \pm 0.6$ & $16.1 \pm 3.2$ & 20 \\
\hline
\end{tabular}

${ }^{a}$ Chlorophyll $a$ from 9 samples only. '(Personal observation).

Table 4. Summed $\mathrm{NH}_{4}^{+}+\mathrm{NO}_{3}^{-}+$urea-N absolute uptake rate in nmol $\mathrm{l}^{-1} \mathrm{~h}^{-1}, \mathrm{f}$-ratio $\left(\mathrm{NO}_{3}^{-}\right.$uptake rate divided by summed uptake rate) and $\mathrm{NH}_{4}^{+}$and urea uptake rate as \% of summed uptake rate in the ice algal samples, in one quantitative ice algal sample incubated in situ, in the water column in the marginal ice zone (MIZ), and at Stations 905.947 and 961 south of MIZ. Mean \pm standard error and number of samples $(n)$ are given. n.a. $=$ no values available.

\begin{tabular}{|c|c|c|c|c|c|}
\hline Sample & Summed uptakc & $\mathrm{f}$ & $\% \mathrm{NH}_{4}^{+}$ & $\%$ Urea & $\mathrm{n}$ \\
\hline Ice algac & $500 \pm 191$ & $0.92 \pm 0.02$ & $6 \pm 2$ & $2 \pm 1$ & 15 \\
\hline Ice algae, in situ & n.a. & 0.96 & 0 & 3 & 1 \\
\hline Water column, MIZ & $10 \pm 3$ & $0.92 \pm 0.01$ & $5 \pm 1$ & $3 \pm 1$ & 15 \\
\hline $905,26 \mathrm{~m}$ & 4 & 0.00 & 80 & 20 & 1 \\
\hline $947.30 \mathrm{~m}$ & 10 & 0.74 & 24 & 2 & 1 \\
\hline $961,30 \mathrm{~m}$ & 15 & 0.00 & 100 & 0 & 1 \\
\hline
\end{tabular}

(Personal observation).

corresponding mean $\mathrm{N}$ growth rate, assuming 12 hours daily uptake, was $0.04 \pm 0.01$ doubl. $\mathrm{d}^{-1}$ (mean and $\mathrm{SE}, \mathrm{n}=15$ ). The $\mathrm{N}$ growth rates are minimum estimates because nitrogen was taken up at a reduced rate in the dark (Fig. 2 and Table 5 ), and because they have not been corrected for non-phytoplankton nitrogen. Reported growth rates for ice algae are 3-8 times higher (see Palmisano \& Sullivan 1985). The ratio between $\mathrm{NO}_{3}^{-}$uptake rate and summed uptake rate (fratio) is often used as an index of new production (Eppley \& Peterson 1979; Harrison et al. 1987). The f-ratio was very high, and $\mathrm{NH}_{4}^{+}$and urea were negligible as nitrogen sources in the ice algal communities. High $\mathrm{NH}_{4}^{+}$concentrations were found in the ice/seawater interface at some of the stations (Table 2) but not, however, in the uptake samples. The sampling procedure and dilution with filtered sea water may have diluted away any elevated $\mathrm{NH}_{4}^{+}$concentrations in the uptake samples. The relative importance of the three nitrogen sources may therefore be biased, and possibly the true mean f-ratio was lower than 0.92 . This seems unlikely, however, because a similar $\mathrm{f}$-ratio was found in one in situ incubation (Table 4). A similar f-ratio was also found in the water column within the ice (Table 4). The same sampling and dilution procedures were used in similar experiments in Antarctica during the EPOS cruise, leg 1, in 1988. The infiltration 

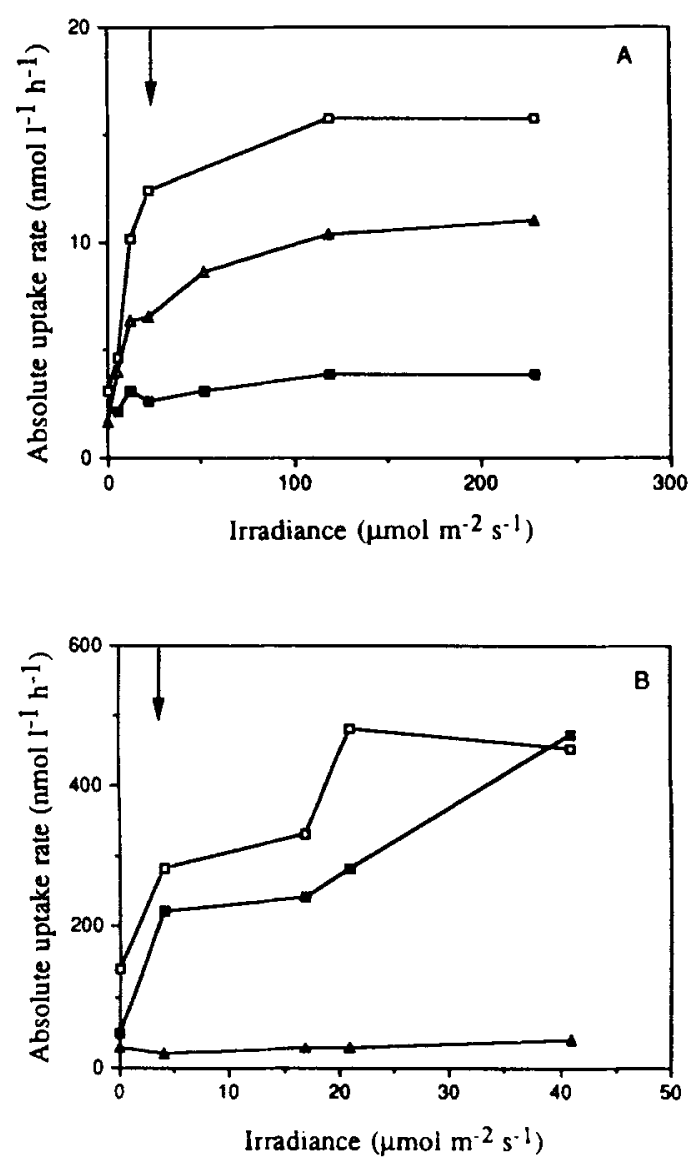

Fig. 2. Maximum absolute uptake rates of $\mathrm{NH}_{\ddagger}^{-}(\square), \mathrm{NO}_{3}^{-}(\square)$ and urea-N $(\triangle)$ as functions of irradiance. A. Samples from the subsurface chlorophyll maximum at Station $961.30 \mathrm{~m} .4$ June 1987: and B. Samples from the sub-ice assembiage at Station HK. 26 May 1988. The arrows indicate the irradiance at the sampling depits at noon.

assemblage (Horner et al. 1988) was the dominating ice algal community encountered during the EPOS cruise, and the mean f-ratio was 0.96 $(\mathrm{SD}=0.05, n=5$; $\mathrm{S}$. Kristiansen \& E. E. Syvert- sen, unpubl. values). Olson (1980) found a lower mean $\mathrm{f}$-ratio $(0.71, \mathrm{n}=2)$ in ice algal communities in Antarctica but also claims that his $\mathrm{f}$-ratios were minimum estimates. The f-ratio was 0 in the subsurface maximum at Stations 905 and 961 (Table 4). At the biomass-rich Station 947 , however, the f-ratio was 0.74 at $30 \mathrm{~m}$ depth (Table 4). Similar variation in the $f$-ratio has been found in the subsurface chlorophyll maximum earlier (Kristiansen \& Lund 1989).

Typical maximum absolute nitrogen uptake rate versus irradiance curves from the subsurface chlorophyll maximum and the sub-ice assemblage are given in Fig. 2. The maximum absolute nitrogen uptake rates in the subsurface chlorophyll maximum were light-saturated at the same irradiance as carbon uptake $\left(91 \mu \mathrm{mol} \mathrm{m} \mathrm{m}^{-2} \mathrm{~s}^{-1}\right.$ at Station 905; Rey, pers. commun.). No definite light-saturation level was found for $\mathrm{NO}_{3}^{-}$and urea uptake in the sub-ice assemblage. It is reasonable, however, based on the values in Fig. 2, to assume that the maximum absolute $\mathrm{NO}_{3}^{-}$and urea uptake rates in the sub-ice assemblage were light-saturated at about $100 \mu \mathrm{mol} \mathrm{m} \mathrm{m}^{-2} \mathrm{~s}^{-1}$. The maximum $\mathrm{NH}_{4}^{+}$uptake rate was light-saturated at $21 \mu \mathrm{mol}$ $\mathrm{m}^{-2} \mathrm{~s}^{-1}$ (Fig. 2b). These light-saturation levels are within the range of published values for $C$ uptake in ice algal communities (Burkholder \& Mandelli 1965; Palmisano \& Sullivan 1985; Palmisano et al. 1985; Horner 1985). Maximum nitrogen uptake rates at in situ irradiance are calculated as percent of light-saturated rates in Table 5. A linear relationship was assumed between maximum nitrogen uptake rates and irradiances $<21-41 \mu \mathrm{mol} \mathrm{m} \mathrm{m}^{-2} \mathrm{~s}^{-1}$ in making the calculation. In situ irradiance at noon was low both in the subsurface chlorophyll maximum and in the sub-ice assemblage (Table 5). Even though the $\mathrm{Chl} / \mathrm{C}$ ratios indicated shade-adapted cells in both communities (Table 6), the maximum nitrogen uptake rates at all stations in Table 5 were light-limited.

Table 5. Irradiance at sample depth at noon (I, in $\left.u m o l \mathrm{~m}^{-2} \mathrm{~s}^{-1}\right)$ and as percentage of surfacc irradiance (\% $\mathbf{I}$ ). and in situ maximum uptake rate of $\mathrm{NO}_{5}^{-} \mathrm{NH}_{+}$and urea as percentage of light-saturated maximum rates in the water column south of the marginal ice zone and in the sub-ice assemblage. n.a. = no values available

\begin{tabular}{|c|c|c|c|c|c|c|}
\hline Station & Depth & 1 & $\% I$ I. & ri $\mathrm{NO}_{3}^{-}$ & $\% \mathrm{NH}_{+}^{*}$ & \% Urea \\
\hline 915 & 26 & 6 & 2 & 46 & 61 & 72 \\
\hline 947 & 30 & 0.5 & 0.6 & 12 & 28 & 46 \\
\hline 961 & 30 & 26 & 6 & 67 & 79 & 59 \\
\hline 11 & ice algace & 3 & n.a. & $<59$ & 68 & $<53$ \\
\hline $\mathrm{HK}$ & ice algas & 3 & n.a. & $<29$ & 44 & $<71$ \\
\hline
\end{tabular}


Table 6. Concentration of chlorophyll $a\left(\mu \mathrm{g}^{-1}\right)$, ratio between chlorophyll $a$ and particulate organic carbon $(\mathrm{Chl} / \mathrm{C}$ in $\mathrm{g} / \mathrm{g})$, and concentrations of $\mathrm{NO}_{3}^{-}, \mathrm{NH}_{4}^{+}$and urea- $\mathrm{N}$ in $\mu \mathrm{mol} \mathrm{l}^{-1}$ in the water column south of the marginal ice zone and in the sub-ice assemblage. The ice algal samples were not collected quantitatively, n.a. $=$ no values available.

\begin{tabular}{rlccccc}
\hline Station & Depth & Chl & $\begin{array}{l}\text { Chl/C } \\
(\times 1000)\end{array}$ & $\mathrm{NO}_{3}^{-}$ & $\mathrm{NH}_{+}^{+}$ & Urea-N \\
\hline 905 & 10 & 0.56 & 4.1 & 0.0 & 0.09 & 0.20 \\
905 & 26 & 7.04 & 47.1 & 0.0 & 0.53 & 0.17 \\
961 & 10 & 0.19 & 1.9 & 0.0 & 0.17 & 0.03 \\
961 & 30 & 6.72 & 13.8 & 0.0 & 0.21 & 0.03 \\
947 & 10 & 5.09 & 17.7 & 0.4 & 0.17 & 0.12 \\
947 & 30 & 3.49 & 12.7 & 2.6 & 0.59 & 0.04 \\
11 & ice algae & 3844 & 58.7 & 7.3 & 0.10 & n.a. \\
HK & ice algae & 8120 & n.a. & 4.8 & 0.03 & 0.03 \\
\hline
\end{tabular}

aligotrophic surface laycr.

Except for $\mathrm{NH}_{4}^{+}$at Station $905(26 \mathrm{~m})$, the nutrient concentrations at Stations 905 and 961 were low, close to the detection limit (Table 6), and it is not possible to decide whether the in situ absolute uptake rates of $\mathrm{NH}_{4}^{+}$and urea in the subsurface chlorophyll maximum were light-limited or not. The f-ratio was 0 at both stations (Table 4), and the in situ absolute $\mathrm{NO}_{3}^{-}$uptake was clearly substrate-limited at both stations. The $\mathrm{NH}_{4}^{+}$concentration was significantly higher in the subsurface chlorophyll maximum at Station 905 $(26 \mathrm{~m})$ than in the oligotrophic surface layer above (Station 905, $10 \mathrm{~m}$; Table 6). Probably the in situ $\mathrm{NH}_{4}^{+}$uptake rate was light-limited in the subsurface chlorophyll maximum at Station 905. Station 947 was sampled at $30 \mathrm{~m}$ depth, in $\mathrm{NO}_{3}^{-}$rich water below $1 \%$ light depth (Table 6 ). However, the phytoplankton biomass was high in the upper $50 \mathrm{~m}$, and no pronounced subsurface chlorophyll maximum was found at this station. The maximum absolute uptake versus irradiance curves

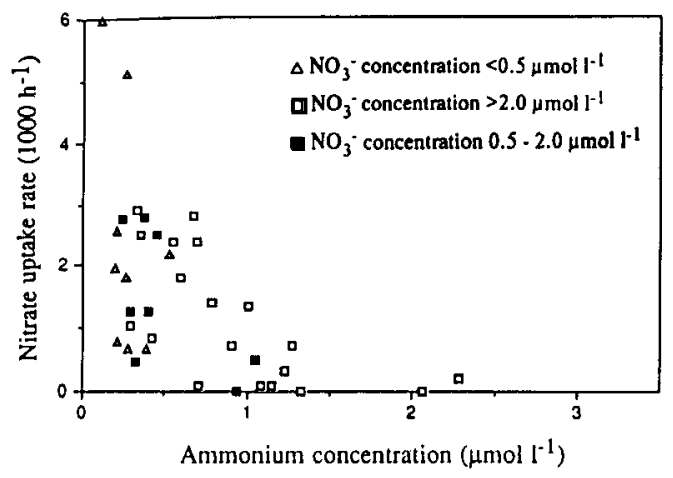

Fig. 3. Maximum specific $\mathrm{NO}_{3}^{-}$uptake rate as a function of $\mathrm{NH}_{4}^{+}$concentration in the subsurface chlorophyll maximum. were similar to the curves in Fig. 2A except that the $\mathrm{NO}_{3}^{-}$curve was higher than the curves for both $\mathrm{NH}_{4}^{+}$and urea. $\mathrm{NO}_{3}^{-}$was the major nitrogen source (f-ratio $=0.74$, Table 4 ), and the in situ uptake rates of both $\mathrm{NO}_{3}^{-}$and $\mathrm{NH}_{4}^{+}$probably were light-limited at this depth.

High concentrations of $\mathrm{NH}_{4}^{+}$and of urea have been found in the subsurface chlorophyll maximum (Table 2; Kristiansen \& Lund 1989). These high $\mathrm{NH}_{4}^{+}$and urea concentrations were obviously produced by heterotrophic processes in the water column. Typical values for irradiance in the subsurface chlorophyll maximum at noon were $<25 \mu \mathrm{mol} \mathrm{m}{ }^{-2} \mathrm{~s}^{-1}$, and the irradiance varied with global radiation (F. Rey pers. commun.). It is suggested that light-limitation of the in situ uptake rates of $\mathrm{NH}_{4}^{+}$(and urea) was one major reason for this accumulation of nutrients. The data indicate that this actually was happening at Stations 905 and 947 (Tables 5 and 6). $\mathrm{NH}_{4}^{+}$ concentrations $>0.8-1.0 \mu \mathrm{moll}^{-1}$ reduced the maximum $\mathrm{NO}_{3}^{-}$uptake rate drastically (Fig. 3; Kristiansen \& Lund 1989). At some of the $\mathrm{NO}_{3}^{-}$-rich stations the maximum $\mathrm{NO}_{3}^{-}$uptake rate was close to zero, and consequently the in situ absolute $\mathrm{NO}_{3}^{-}$uptake rate also was low. Indirectly then, light limitation of the in situ absolute $\mathrm{NH}_{4}^{+}$uptake rate may affect the in situ absolute $\mathrm{NO}_{3}^{-}$uptake rate.

The in situ irradiance during sampling of the ice algae was well below the optimum irradiance for nitrogen uptake (Fig. 2A, Table 5). Irradiances at the surface were not measured but both samples were collected on dark snowy days. The concentration of $\mathrm{NO}_{3}^{-}$in the sub-ice assemblage was high (Table 6), and the in situ $\mathrm{NO}_{3}^{-}$ uptake rate was probably light-limited. The 
$\mathrm{NH}_{4}^{+}$and urea concentrations were low, and it is not possible to decide if the in situ rates of these two nitrogen sources were light-limited or not. The absolute uptake rates of $\mathrm{NH}_{4}^{+}$and urea were very low in the sub-ice assemblage, however, and both were negligible as nitrogen sources for the ice algae (Table 4). Typical under-ice irradiance in the Barents Sea was between 2 and $30 \mu \mathrm{mol}$ $\mathrm{m}^{-2} \mathrm{~s}^{-1}$, the highest values measured on sunny days (E. N. Hegseth pers. commun.). The $\mathrm{NO}_{3}^{-}$concentration in the ice algal communities at the stations in Fig. 1 was $2.6-10.8 \mu \mathrm{mol}^{-1}$, and the in situ uptake rate of $\mathrm{NO}_{3}^{-}$, the main nitrogen source at these stations, was probably lightlimited.

Acknowledgements. - We acknowledge the generous assistance of the other cruise participants and the captains and crews of R/V G. O. SARS, R/V LANCE, K/V ANDENES, K/V NORDKAPP, and K/V SENJA. We thank E. N. Hegseth and E. E. Syvertsen for providing ice algal samples; $\mathrm{F}$. Rey for chlorophyll, $\mathrm{NO}_{3}^{-}$and some of the particulate organic carbon and nitrogen data from the water column; E. N. Hegseth for chlorophyll data and some of the particulate organic carbon and nitrogen data from the ice algal samples, and B. G. Mitchell for light data. The incubations on board R/V LANCE were done by E. E. Syvertsen. We also thank P. A. Wheeler for reviewing an earlier draft of the manuscript. This work is a part of the Norwegian Rescarch Program for Marine Arctic Ecology (Pro Mare) and was in part financed by the Norwegian Research Council for Science and the Humanities (NAVF) and the Norwegian Ministry of the Environment.

\section{References}

Burkholder, P. R. \& Mandelli, E. F. 1965: Productivity of microalgae in Antarctic sea ice. Science 149, 872-874.

Eppley, R. W. \& Peterson, B. J. 1979: Particulate organic matter flux and planktonic new production in the decp ocean. Nature 282, 677-680.

Harrison, W. G., Platt, T. \& Lewis, M. R. 1987: f-Ratio and its relationship to ambient nitratc concentration in coastal waters. J. Plankton Res. 9. 235-248.

Horner, R. 1985: Ecology of sea ice microalgae. Pp. 83-103 in Horner, R. (ed.): Sea ice biota. CRC Press, Florida.

Horner, R. A., Syvertsen, E. E., Thomas, D. P. \& Lange, C. 1988: Proposed terminology and reporting units for sca ice algal assemblages. Polar Biol. 8, 249-253.

Kristiansen, S. \& Lund. B. Aa. 1989: Nitrogen cycling in the
Barents Sea-I. Uptake of nitrogen in the water column. DeepSea Res. 36, 255-268.

Loeng. H. 1989: Ecological features of the Barents Sca. Pp. 327-365 in Rey, L. \& Alexander, V. (cds.): Proceedings of the Sixth Conference on the Comité Arctique International 1.315 May 1985. E. J. Brill, Leiden.

Lonne, O. J. 1988: A diver-operated electric suction sampler for sympagic (=under-ice) invertebrates. Polar Res. 6, 135136.

Olson. R. J. 1980: Nitrate and ammonium uptake in Antarctic waters. Limnol. Oceanogr. 25. 1064-1074.

Palmisano, A. C. \& Sullivan, C. W. 1985: Growth, metabolism, and dark survival in sea ice microalgac. Pp. 131-146 in Horner, R. (ed.): Sea ice biota. CRC Press. Florida.

Palmisano, A. C., SooHoo, J. B. \& Sullivan. C. W. 1985 : Photosynthesis-irradiance relationships in sea ice microalgae from McMurdo Sound. Antarctica. J. Phycol. 21. 341-346.

Redfield, J. L., Ketchum, B. H. \& Rickards. F. A. 1963: The influence of organisms on the composition of seawater. Pp. 26-77 in Hill, M. N. (cd.): The Sea. Vol. 2. John Wilcy and Sons.

Rey, F. \& Loeng, H. 1985: The influence of ice and hydrographic conditions on the development of phytoplankton in the Barents Sea. Pp. 49-64 in Gray, J. S. \& Christiansen, M. E. (eds.): Marine Biology of Polar Regions and Effects of Stress on Marine Organisms. John Wiley and Sons.

Sakshaug. E. 1989: The physiological ccology of polar phytoplankton. Pp. 61-89 in Rey, L. \& Alexander, V. (eds.): Proceedings of the Sixth Conference on the Comite Arctique International 13-15 May 1985. E. J. Brill, Leiden.

Syvertsen, E. 1986. Pro Mare-tokt med "Lance", mai/juni 1986. Toktrapport fra Isflora-gruppen. Pp. 15-16 in Mehlum, F. (ed.): Rapport fra Norsk Polarinstitutts Pro Mare-tokt med "Lance". Barentshavet 21/5-10/6, 1986. Norsk Polarinst. Rapportserie $n r$. 29. Oslo (in Norwegian).

Syvertsen, E. E. 1987: Isalger. Diatomeer ved iskanten i Batentshavet. Pp. 22-23 in Syvertsen. E. E. (cd.): Rapport fra Pro Mare-tokt 10 med K/V Nordkapp 24. februar-10. mars 1987. Biologisk institutt, Universitet i Oslo. Oslo (in Norwegian).

Syvertsen. E. E. 1988: Isalger. Diatomeer ved iskanten i Barentshavet. P. 25 in Lønne, O. J. (ed.): Rapport, Pro Mare tokt $n r$. 14, med $K / V$ Andenes 18. mai-2. juni 1988. Universitetct i Tromsø. Troms $\emptyset$ (in Norwegian).

Syvertsen. E. E. 1991: Ice algae in the Barents Sca: types of assemblages, origin, fate and role in the ice edge phytoplankton bloom. Pp. 277-287 in Sakshaug. E., Hopkins. C.C.E. \& Øritsland, N. A. (eds.): Proceedings of the Pro Mare Symposium on Polar Marine Ecology, Trondheim. 1216 May 1990. Polar Research 10(1).

Vincent. W. F. 1988: Microbial ecosystems of Antarctica. Cambridge University Press, Cambridge.

Vinje, T. 1987: Norsk Polarinstitutt. Isgruppen. Pp. 12-13 in Syvertsen. E. E. (ed.): Rapport fra Pro Mare-tokt 10 med K/ $V$ Nordkapp, 24. februar-10. mars 1987. Biologisk institutt. Universitetet i Oslo. Oslo (in Norwegian). 